\title{
СИНТЕЗ И АНТИМИКРОБНАЯ АКТИВНОСТЬ СУЛЬФЕНИМИНОВ НА ОСНОВЕ 10-ГИДРОКСИ-ИЗОПИНОКАМФЕИЛ ТИОЛА И ЕГО ТРИФТОРМЕТИЛИРОВАННОГО АНАЛОГА
}

\author{
Н.О. Ильченко', Д.В. Судариков', С.А. Рубцова' \\ 1Лаборатория медицинской химии, Институт химии ФИЦ Коми НЦ УрО РАН, \\ 167000, Россия, Сыктывкар, Первомайская, д.48.
}

DOI: 10.19163/MedChemRussia2021-2021-162

E-mail: albedogrisonat@gmail.com

Направленная химическая модификация биологически активных природных соединений приводит к усилению их активности, в связи с чем данное направление является одним из наиболее востребованных в медицинской химии. Тиолы, полученные из природных монотерпеноидов, являются самостоятельными биологически активными соединениями, при этом они могут быть использованы как интермедиаты в органическом синтезе сульфениминов и сульфиниминов,[1] сульфонамидов,[2] и т.д.

Нами осуществлён синтез сульфениминов на основе миртеналь-производных тиолов и трифторметилированных аналогов этих тиолов, поскольку функционализация фторсодержащими группами приводит к усилению таких свойств как липофильность, мембранная проницаемость и стойкость к биодеградации. Нефторированные соединения подобной структуры проявляют антибактериальную [3], антиоксидантную и мембранопротекторную активности, $[3,4]$ в связи с чем можно оценить степень влияния трифторметильной группы на биологическую активность соединений.
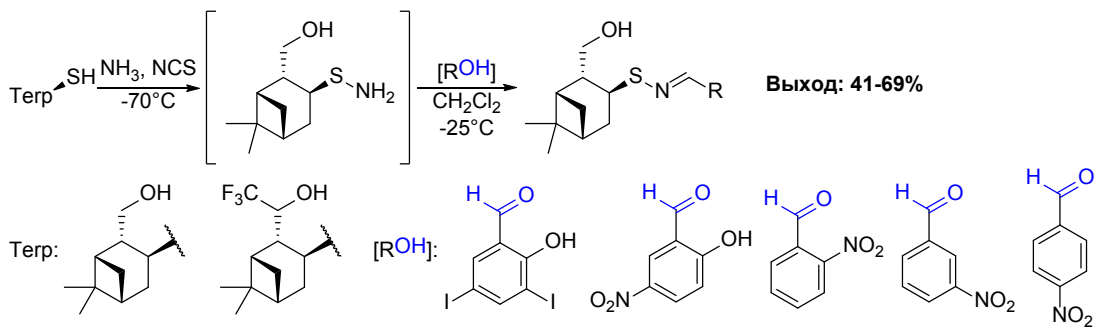

Работа выполнена при финансовой поддержке Российского фонда фундаментальных исследований (грант 19-03-00951 А) с использованием оборудования Центра Коллективного Пользования (ЦКП) «Химия» Института химии Коми НЦ УрО РАН.

\section{Литература}

[1] L. E. Nikitina, V. A. Startseva, I. A. Vakulenko, I. M. Khismatulina, S. A. Lisovskaya, N. P. Glushko, R. S. Fassakhov, Pharm. Chem. J. 2009, 43, 251-254.

[2] S. Watanabe, T. Fujita, M. Sakamoto, Y. Mino, T. Kitazume, J. Fluor. Chem. 1995, 73, 21-26.

[3] D. Sudarikov, Yu. Krymskaya, P. Slepukhin, et al, Russ. Chem. Bull. 2018, 67, 731-742

[4] D. Sudarikov, Yu. Krymskaya, O. Shevchenko, P. Slepukhin, et al, Chem. Biodiversity. 2019, cbdv.201900413 